\title{
Ovarian Insular Carcinoid Tumor
}

National Cancer Institute

\section{Source}

National Cancer Institute. Ovarian Insular Carcinoid Tumor. NCI Thesaurus. Code C40013.

A carcinoid tumor that arises from the ovary and is characterized by the presence of round cells with abundant eosinophilic cytoplasm forming cribriform patterns. Clinical manifestations of carcinoid syndrome occur in approximately thirty percent of patients. The prognosis is favorable. 